\title{
CITRAAN DALAM ANTOLOGI PUISI SURAT KOPI KARYA JOKO PINURBO
}

\author{
Dodi Bramfi Imanuel ${ }^{1}$, Erlina Zahar ${ }^{2}$, Firman Tara ${ }^{3}$ \\ Program Studi Pendidikan Bahasa dan Sastra Indonesia, \\ Fakultas Keguruan dan Ilmu Pendidikan, Universitas Batanghari, \\ Jambi \\ dodibramvi1998@gmail.com \\ erlina_zahar@yahoo.co.id \\ firmantara14@gmail.com
}

\begin{abstract}
The purpose of this research is to describe the imagery contained in the poetry anthology of Joko Pinurbo's Surat Kopi. This research is qualitative descriptive. The main data in this research is written data in the form of expressions containing imagery elements found in the poetry anthology of Surat Kopi by Joko Pinurbo. The data is collected by using library study techniques focused in analyzing the imagery found in the poetry anthology Surat Kopi by Joko Pinurbo. Meanwhile in analyzing the data, analysis and description techniques were used. From the results of the research, it can be concluded that there are imagery of vision, auditory in the 21 poems in the anthology of Surat Kopi by Joko Pinurbo. The description is as follows, (1) there is a vision imagery in the 21 poems of Surat Kopi by Joko Pinurbo, the 21 poems depict that what the poet sees as if it can also be seen by poetry readers, the imagery of visions found are 19 expressions. (2) there is an image of hearing in 21 poems of Surat Kopi by Joko Pinurbo, in the poem describes that the voice heard by the poet as if it can also be heard by the reader of poetry, the image of hearing found are 7 expressions. (3) there is an image of motion in the 21 poems of Surat Kopi by Joko Pinurbo, in the poem illustrates that the things felt moving by the poet as if also felt directly by the reader of poetry, the image of motion found are 11 expressions. Thus the total imagery found in the 21 poems of Surat Kopi by Joko Pinurbo are 37 expressions.
\end{abstract}

Keywords: analysis, imagery, poem collection

${ }^{1}$ Mahasiswa Program Studi Pendidikan Bahasa dan Sastra Indonesia, Fakultas Keguruan dan Ilmu Pendidikan, Universitas Batanghari, Jambi

${ }^{2}$ Dosen Program Studi Pendidikan Bahasa dan Sastra Indonesia, Fakultas Keguruan dan Ilmu Pendidikan, Universitas Batanghari, Jambi

${ }^{3}$ Dosen Program Studi Pendidikan Bahasa dan Sastra Indonesia, Fakultas Keguruan dan Ilmu Pendidikan, Universitas Batanghari, Jambi 
PENDAHULUAN

Puisi merupakan karya sastra yang masuk dalam golongan lirik. Dibandingkan dengan jenis karya sastra lainnya seperti novel dan drama, puisi memiliki bahasa yang lebih padat dan indah dan pemaknaan dalam puisi adalah multi tafsir. Masing-masing individu dapat memiliki interpretasi sendiri. Bahasa yang digunakan dalam puisi juga bukan merupakan bahasa harian. Pemilihan kata pada puisi sangat selektif dan memperhatikan norma serta keindahan.

Berkaitan dengan keistimewaan puisi yang telah disebutkan di atas, maka dalam memaknai puisi tidak bisa dilakukan secara asal. Karena sering kali bahasa dalam puisi itu merupakan sebuah tanda yang menyimpang dari arti sebenarnya dan memiliki multi makna dengan bahasa kias. Oleh karena itu, diperlukan suatu pengkajian puisi untuk memperoleh kesatuan makna yang utuh dari suatu puisi. Puisi dapat dikaji dengan berbagai pendekatan, baik secara struktural maupun semiotik.

Puisi merupakan karya sastra yang perkembangannya cukup pesat dan banyak digemari oleh pembaca. Hal ini bisa dibuktikan dengan hadirnya berbagai macam karya puisi dalam bentuk antologi. Selain itu, menurut pengamatan penulis setiap diadakannya perlombaan baik membaca maupun menulis puisi para peserta yang hadir cukup banyak. Kemudian fenomena yang bisa kita lihat sehari-hari bukti dari bentuk kebutuhan dan kecintaan masyarakat terhadap puisi adalah dengan banyaknya pengguna media sosial yang mengutarakan suasana hati atau menyampaikan pesan untuk seseorang melalui puisi. Puisi bisa kita artikan sebagai ungkapan perasaan dari penyair yang dirangkai menjadi suatu bentuk tulisan dan disusun ke dalam bait dengan kata yang sangat padat namun mengandung berjuta makna. Puisi juga dirangkai dengan kata yang indah yang tersusun dari pengalaman pribadi maupun pengalaman orang lain dalam kehidupan sehari-hari. Inilah yang menjadi alasan peneliti mengambil kajian puisi.

Puisi Joko Pinurbo begitu hebat dalam melahirkan karya-karya sastra. Joko Pinurbolahir di Pelabuhan Ratu, Sukabumi, Jawa Barat, 11 Mei 1962; umur 57 tahun adalah salah seorang penyair terkemuka Indonesia yang karya-karyanya telah menorehkan gaya dan warrna tersendiri dalam dunia puisi Indonesia. Ia menyelesaikan pendidikan terakhirnya di Institut Keguruan dan Ilmu Pendidikan (sekarang Universitas) Sanata Dharma, Yogyakarta. Kegemarannya mengarang puisi ditekuninya sejak di Sekolah Menengah Atas.Atas pencapaiannya, Jokpinurbo telah memperoleh berbagai penghargaan: Penghargaan Buku Puisi Dewan Kesenian Jakarta (2001), Sih Award (2001), Hadiah Sastra Lontar (2001), Tokoh Sastra Pilihan Tempo (2001, 2012), Penghargaan Sastra Badan Bahasa (2002, 2014), Kusala Sastra Khatulistiwa (2005, 2015), South East Asian (SEA) Write Award (2014). Penyair yang bermukim di Yogyakarta ini sering diundang ke berbagai pertemuan dan festival sastra. Karyakaryanya telah diterjemahkan antara lain ke dalam bahasa Inggris, Jerman, dan Mandarin. Sejumlah puisinya juga telah dimusikalilasi antara lain oleh Oppie Andaresta dan Ananda Sukarlan dengan indah dan menarik.(https://id.wikipedia.org/wiki/Jo ko_Pinurbo -04-09-2019).

Puisi-puisi Joko Pinurbo merupakan perpaduan narasi, humor, dan ironi. Ia piawai menggunakan dan mengolah citraan yang mengacu pada peristiwa dan objek sehari-hari dengan bahasa yang cair tapi tajam. Puisi- 
puisinya banyak mengandung refleksi dan kontemplasi yang menyentuh absurditas sehari-hari. Di sisi lain, Jokpin gemar mempermainkan dan mendayagunakan keunikan kata-kata bahasa Indonesia sehingga banyak puisinya hanya dapat dibaca dan dinikmati dalam bahasa Indonesia. Melihat rekam jejak Joko Pinurbo dalam menghasilkan karya sastra dan berbagai macam penghargaan yang telah diperolehnya jelas membuktikan bahwa dia adalah sosok yang memiliki jiwa seni yang sangat tinggi. (https://id.wikipedia.org/wiki/Joko-4-092019)

Membaca puisi merupakan suatu proses komunikasi yang agak rumit. Ada komunikasi langsung antara pembaca dan puisi, tetapi pembaca belum tentu bisa berkomunikasi secara langsung dengan si penyair. Lewat puisinya itulah penyair 'berkomunikasi' dengan pembaca, tetapi karena puisi disusun dalam bahasa, bisa saja apa yang diniatkan penyair tidak sampai ke pembaca (Damono, 2005:33). Bila kita perhatikan memang tidak semua orang bisa memahami puisi sepenuhnya. Karena di dalam puisi akan kita jumpai teks-teks yang memiliki medan makna yang sangat luas. Hanya sebagian orang yang memiliki intelektualitas tertentu saja yang bisa menerjemahkan maksud dari puisi tersebut.

Sebuah karya sastra akan sangat bermakna jika pembaca dapat mengetahui dan menghayati makna yang terkandung di dalamnya. Memahami suatu karya sastra bukan hanya sekedar membaca dan menikmatinya, namun juga harus mampu menghayati makna yang terkandung dalam karya sastra itu. Melalui karya sastra pembaca dapat menemukan manfaat yang berharga, salah satunya dengan memahami makna sebuah puisi. Dalam memahami makna puisi diperlukan kejelian dan kecermatan dalam membacanya. Puisi tidak bisa terlepas dari struktur fisik dan struktur batin yang sangat berkaitan dalam membangun sebuah puisi. Dalam struktur fisik puisi terdapat citraan. Salah satu langkah yang harus dilakukan untuk memahami karya sastra adalah melalui analisis atau penguraian. Melalui analisis, sebuah karya sastra yang kompleks dan rumit dapat dimengerti sehingga tidak mengurangi unsur keindahan yang terkandung di dalamnya.

Puisi banyak memanfaatkan kekuatan citraan terutama dalam puisi Jokpin ini untuk melukiskan sesuatu agar mudah diimajinasikan, dengan adanya citraan pembaca seolah-olah dapat tergugah tanggapan inderanya. Dalam citraan akan menimbulkan suatu kesan dan pikiran yang dimunculkan dari kata, kelompok kata, atau kalimat di dalam puisi. Pada penelitian ini, penulis melakukan penelitian agar dapat menggali unsur pembangun, seperti unsur citraan dimana di dalam karya sastra citraan dapat digunakan untuk mengelompokan dan menilai karya sastra. citraan merupakan salah satu cara memanfaatkan sarana kebahasaan. Dengan adanya citraan pembaca dengan mudah menentukan atau menerjemahkan maksud dari sebuah puisi. Citraan dipergunakan penyair untuk memperkuat gambaran pikiran dan perasaan pembaca. Hal tersebutlah yang menjadi acuan khusus bagi penulis untuk melakukan penilaian terhadap sebuah karya sastra yaitu dengan menganalisis puisi. Puisi banyak memanfaatkan kekuatan citraan untuk melukiskan sesuatu agar mudah diimajinasikan, dengan adanya citraan pembaca seolah-olah dapat tergugah tanggapan inderanya.

Berdasarkan uraian di atas, penelitian ini penting untuk dilakukan sehingga dapat memberikan manfaat 
bagi pembaca. Maka dari itu penelitian ini dituangkan dengan judul, " Citraan dalam Antologi Puisi Surat Kopi karya Joko Pinurbo".

Berdasarkan latar belakang di atas masalah yang teridentifikasi adalah citraan. Menurut Pradopo, (2014:82) citraan/imaji terbagi menjadi tujuh yakni, citraan penglihatan, citraan pendengaran, citraan perabaan, citraan penciuman, citraan pencecapan, citraan pemikiran dan citraan gerak, sedangkan objek kajian yang akan di teliti pada penelitian ini adalah antologi puisi Surat Kopi karya Joko Pinurbo yang berjumlah 114 puisi.

Berdasarkan identifikasi masalah terlihat bahwa kajian ini cukup luas oleh karena itu perlu adanya pembatasan. Maka dibatasi hanya fokus pada tiga dari tujuh citraan yang ada yaitu, citraan penglihatan, citraan pendengaran, dan citraan gerak. Selain itu, hanya dianalisis 21 puisi dari 114 puisi yang terdapat dalam antologi puisi Surat Kopi karya Joko Pinurbo dengan metode acak. Puisi tersebut sebagai berikut: 1) Lampu, 2) Hati Hujan, 3) Doa Hujan, 4) Gardu, 5) Kursi, 6) Haus, 7) Salam2, 8) Mata Ibu, 9) Kicau, 10)Malam Saya, 11) Perjamuan, 2, 12) Banjir, 1, 13) Banjir, 2, 14)Surga Kecil, 15)Tahun Baru, 1, 16) Akhir Pekan,1 17) Kepala, 3, 18) Habis Hujan. 19) Mendarat, 2, 20) Pulang, 21) Kota Kecil, 2.

Berdasarkan uraian yang terdapat pada batasan masalah di atas, maka pertanyaan penelitian ini adalah sebagai berikut.

1. Bagaimanakah citraan penglihatan dalam antologi puisi Surat Kopi karya Joko Pinurbo?

2. Bagaimanakah citraan pendengaran dalam antologi puisi Surat Kopi karya Joko Pinurbo?
3. Bagaimanakah citraan gerak dalam antologi puisi Surat Kopi karya Joko Pinurbo?

Berdasarkan fokus dan pertanyaan penelitian tersebut, maka tujuan penelitian ini adalah sebagai berikut.

1. Mendeskripsikan citraan penglihatan dalam antologi puisi Surat Kopi karya Joko Pinurbo.

2. Mendeskripsikan citraan pendengeran dalam antologi puisi Surat Kopi karya Joko Pinurbo.

3. Mendeskripsikan citraan gerak dalam antologi puisi Surat Kopi karya Joko Pinurbo.

Dalam penelitian ini ada dua manfaat yang dapat diambil, yaitu manfaat teoretis dan manfaat praktis.

Hasil penelitian ini dapat memperkaya pengetahuan di bidang kesusastraan secara khusus mengapresiasi puisi. Dapat menambah wawasan bagi peneliti dalam mengkaji citraan di dalam cipta sastra puisi. Hasil penelitian ini juga dapat bermanfaat untuk pengembangan teori-teori penelitian

Manfaat praktis penelitian ini adalah sebagai berikut.

1. Hasil penelitian ini dapat memberikan informasi tentang citraan yang terdapat di dalam puisi.

2. Hasil penelitian ini dapat memberikan pemahaman kepada masyarakat untuk memahami makna yang terkandung dalam sebuah karya puisi.

3. Bagi peneliti selanjutnya penelitian ini bisa menambah refrensi mereka jika melakukan penelitian dalam kajian yang berbeda.

\section{METODE PENELITIAN}

Dalam penelitian sastra ada beberapa pendekatan atau sudut pandang 
peneliti dalam menganalisis sebuah karya.. Perbedaan sudut pandang kemudian memunculkan adanya berbagai jenis penelitian sastra. Oleh karena itu, jenis penelitian sastra tergantung dari sudut pandang yang dipakai peneliti (Rahima, 2017:1). Jenis penelitian termasuk penelitian kualitatif karena didasarkan pada pendekatan kualitatif . Penelitian kualitatif adalah penelitian yang berupaya untuk menyajikan dunia sosial, dan perspektifnya di dalam dunia, dari segi konsep, prilaku, persepsi, dan persoalan tentang manusia yang diteliti Richie dalam (Moleong, 2014: 6). Selain itu "Penelitian kualitatif adalah penelitian yang menggunakan latar ilmiah, dengan maksud menafsirkan fenomena yang terjadi dan dilakukan dengan jalan melibatkan berbagai metode yang ada" (Denzin dan Lincoln, 2014: 5). Penelitian ini bertujuan untuk memahami fenomena tentang apa yang dialami oleh subjek penelitian misalnya prilaku, persepsi, motivasi, tindakan, dll, secara utuh, dan dengan cara deskripsi dalam bentuk kata-kata dan bahasa.

Penelitian merupakan kegiatan ilmiah, caranya harus sistematis atau prosedural" (Siswantoro, 2014). Seorang peneliti harus bekerja secara teratur di dalam upaya memecahkan masalah. Peneliti tidak bisa bergerak dari satu aspek ke aspek yang lain secara serampangan.

Penelitian ini bersifat deskriptif kualitatif. "Metode deskriptif dapat diartikan sebagai prosedur pemecahan masalah yang diselidiki dengan menggambarkan atau melukiskan keadaan subjek dan objek penel 32 (novel, drama, cerita pendek, puisi) saat sekarang berdasarkan fakta-iмn yang tampak atau sebagaimana adanya"

Penelitian kualitatif dengan metode deskriptif adalah penelitian yang menggambarkan dan mengungkapkan sesuatu melalui kata-kata baik lisan maupun tulisan berdasarkan fakta atau fenomena tentang apa yang dialami oleh subjek penelitian. Metode ini digunakan untuk mendeskripsikan data-data tentang aspek citraan dalam antologi puisi Surat Kopi karya Joko Pinurbo.

"Data adalah sumber informasi yang diseleksi sebagai bahan analisis" (Siswantoro, 2014:70). Jadi, kualitas dan ketepatan pengambilan data tergantung pada ketajaman menyeleksi yang dipadu oleh penguasaan konsep atau teori. Data dalam penelitian ini adalah kutipan citraan yang terdapat dalam antologi puisi Surat Kopi karya Joko Pinurbo.

Sumber data terkait dengan subjek penelitian dari mana data diperoleh. Subjek penelitian sastra adalah puisi. Sumber data yaitu buku antologi puisi Surat Kopi karya Joko Pinurbo.

"Teknik pengumpulan data merupakan langkah paling strategis dalam penelitian, karena tujuan utama dari penelitian adalah mendapatkan data" (Sugiyono, 2013:224). Teknik pengumpulan data dalam penelitian ini menggunakan teknik studi pustaka dan analisis citraan penglihatan, pendengaran, dan gerak yang terdapat dalam antologi puisi Surat Kopi karya Joko Pinurbo.

Langkah-langkahnya teknik penhumpulan data, dijelaskan sebagai sebagai berikut.

1. Peneliti membaca keseluruhan puisi yang akan diteliti secara cermat dan berulang-ulang. Hal ini dilakukan untuk mencermati jenis citraan apa saja yang terdapat dalam antologi puisi Surat Kopi karya Sapardi Joko Pinurbo.

2. Peneliti menandai dan mencatat bagian kata-kata atau kalimat-kalimat 
yang berhubungan dengan aspek citraan puisi.

3. Peneliti mencatat data yang berhubungan dengan aspek citraan puisi.

4. Peneliti mengumpulkan data sesuai dengan aspek citraan puisi.

5. Setelah data terkumpul, kemudian dikelimpokkan data sesuai dengan aspek-aspek yang akan diteliti yaitu: Citraan penglihatan, citraan pendengaran, dan citraan gerak yang terdapat dalam antologi puisi Surat Kopi karya Joko Pinurbo.

6. Peneliti mengklasifikasikan data sesuai dengan aspek citraan puisi.

Analisis data dilakukan setelah data terkumpul dengan tahapan sebagai berikut.

1. Data yang sudah diklafisikasikan, dimasukkan ke dalam tabel tabulasi data.

2. Menganalisis data yang sesuai dengan aspek penelitian yang terkandung dalam isi teks puisi.

3. Data yang sudah dianalisis, kemudian dideskripsikan sesuai dengan aspek-aspek penelitian yang terkandung dalam isi teks puisi.

4. Setelah data dianalisis dan dideskripsikan, langkah selanjutnya penulis tidak langsung menyimpulkan. Untuk memperoleh hasil yang akurat penulis melakukan keabsahan data melalui triangulasi data. Adapun langkah-langkah keabsahan data penulis lakukan sebagai berikut.

a. Data-data penelitian yang telah dianalisis selanjutnya disesuaikan dengan teori yang penulis pakai sebagai landasan studi kepustakaan.

b. Data yang telah dianalis, kemudian dicocokkan dengan metode penelitian yang digunakan untuk meneliti penelitian ini. c. Penelitian ini penulis konsultasikan kepada pakar untuk mendapatkan hasil penelitian yang akurat. Dalam hal ini penulis mengkonsultasikan kepada dosen pembimbing.

d. Data yang sudah dianalisis dan dideskripsikan kemudian disimpulkan.

\section{HASIL DAN PEMBAHASAN}

Setelah menganalisis citraan penglihatan, citraan pendengaran, dan citraan gerak terhadap 21 puisi dalam kumpulan puisi Surat Kopi karya Joko Pinurbo maka dapat duideskripsikan sebagai berikut.

1. Terdapat 19 kutipan citraan penglihatan di dalam 14 puisi Surat Kopi karya Joko Pinurbo,

2. Terdapat 7 kutipan citraan pendengaran di dalam 6 puisi Surat Kopi karya Joko Pinurbo.

3. Terdapat 11 kutipan citraan gerak di dalam 9 puisi Surat Kopi karya Joko Pinurbo.

4. Sehingga seluruh kutipan dari ketiga citraan itu terdapat 37 kutipan dari 21 puisi Surat Kopi karya Joko Pinurbo.

Penelitian ini membahas tentang citraan penglihatan, citraan pendengaran, dan citraan gerak dalam puisi Surat Kopi karya Joko Pinurbo. Pembahasan ini mengenai citraan tersebut dijelaskan sebagai berikut.

\section{Citraan Penglihatan}

Citraan penglihatan adalah citraan yang timbul oleh penglihatan. Citraan ini memberikan rangsangan kepada indera penglihatan yaitu mata. Dalam antologi puisi Surat Kopi karya Joko Pinurbo citraan penglihatan dapat dilihat dalam kutipan berikut.

Kutipan 1 
"Dalam sebongkah batu ada hati hujan yang sudah beku" (Hal 22).

Pada penggalan bait puisi tersebut, kutipan sebongkah batu merupakan bagian dalam citraan penglihatan. Kutipan tersebut menggambarkan bahwa seorang pengarang membayangkan bahwa ada sebuah batu. Di mana pengarang menginginkan bahwa apa yang ia lihat juga di lihat oleh pembaca.

Kutipan 2 27).

"Seekor anjing sibuk melamun" (hal

Pada penggalan bait puisi tersebut, terdapat citraan penglihatan. Terlihat dalam kata Seekor anjing yang dimaksudkan oleh pengarang dengan menggambarkan pada bait puisinya, bahwa ada seekor anjing yang sedang melamun.

Kutipan 3

"Tundukkan kepalamu. Hujan sedang mengantar bangkai tikus" (Hal 36)

Pada penggalan bait puisi tersebut, terdapat citraan penglihatan. Terlihat dalam kata tundukkan kepalamu yang dimaksudkan oleh pengarang bahwa ia ingin menggugah daya bayang pembaca untuk melihat seakan-akan ada seseorang yang sedang menundukkan kepala.

Kutipan 4

"Malam ketika bulan mengenakan baju abu-abu" (Hal 63).

Pada penggalan bait puisi tersebut, terdapat kutipan yang mana pengarang menggunakan diksi yang tepat untuk merangsang daya bayang pembaca sehingga pembaca digiring melihat seseorang mengenakan baju abuabu. Pilihan kata yang digunakan pengarang bertujuan untuk menceritakan apa yang dilihatnya sehingga pembaca juga dapat melihat hal tersebut.

Kutipan 5
"Di kamar tidur dan kamar belajarnya yang berantakan" (Hal 82).

Pada penggalan bait puisi tersebut, terdapat citraan penglihatan pada kata berantakan. Pengarang ingin menggugah daya bayang pembaca bahwa seolah-olah melihat sebuah kamar yang tidak rapi dan berantakan.

\section{Citraan Pendengaran}

Citraan pendengaran adalah citraan yang menghasilkan dengan menyebutkan atau menguraikan bunyi suara. Citraan ini memberikan rangsangan kepada indera pendengaran, sehingga kata-kata itu seolah-olah mengeluarkan bunyi, dan pembaca dapat mengungkapkan bunyi. Dalam antologi puisi Surat Kopi karya Joko Pinurbo citraan pendengaran dapat dilihat dalam kutipan berikut.

Kutipan 5

"Doa hujan yang merdu" (Hal 23).

Kutipan puisi tersebut, terdapat citraan pendengaran. Pengarang benarbenar bisa merangsang daya indera pendengaran pembaca sehingga pembaca seolah-olah dapat mendengar suara air hujan yang sangat merdu.

Kutipan 6

"Hujan, dan kolam mengobrol tak henti-hentinya." (Hal 28)

Dari penggalan bait puisi tersebut, terdapat citraan pendengaran. Pengarang ingin menyampaikan dan mengajak pembaca untuk membayangkan bahwa hujan dan kolam mampu mengeluarkan suara dan seakanakan mereka mengobrol.

Kutipan 7

"Diiringi tiga letusan petir." (Hal 76).

Dalam penggalan bait puisi tersebut, terdapat kata tiga letusan petir yang mana penyair ingin menggiring daya bayang pembaca bahwa benarbenar terdengar suara petir sebanyak tiga kali. 
Kutipan 8

"Ada anak burung berkicau-kicau memanggil induknya" (Hal 102).

Penggalan bait puisi tersebut, terdapat citraan pendengaran. Pengarang benar-benar bisa merangsang daya indera pendengaran pembaca sehingga pembaca seolah-olah dapat mendengar suara kicauan anak burung yang sedang memanggil induknya.

\section{Kutipan 9}

"Rindu sudah jadi ngeong kucing di balik pintu."(Hal 134).

Penggalan bait puisi tersebut, terdapat citraan pendengaran. Pengarang benar-benar bisa merangsang daya indera pendengaran pembaca sehingga pembaca seolah-olah dapat mendengar suara ngeong kucing dari balik pintu.

\section{Citraan Gerak}

Citraan gerak adalah citraan yang menggambarkan sesuatu yang sesungguhnya tidak bisa bergerak tapi dilukiskan sebagai dapat bergerak ataupun gambaran gerak pada umumnya. Citraan gerak juga sangat produktif dalam karya sastra karena mampu membangkitkan imaji/daya bayang pembaca. Dalam kumpulan puisi Surat Kopi karya Joko Pinurbo citraan gerak dapat dilihat dalam kutipan berikut.

\section{Kutipan 10}

"Dulu saya belajar menulis di bawah lampu teplok" (Hal 3).

Pada penggalan bait puisi tersebut terdapat citraan gerak pada kata menulis. Pengarang ingin mengajak pembaca untuk membayangkan bahwa ada seseorang yang sedang melakukan aktivitas gerak dengan menulis dibawah lampu teplok.

\section{Kutipan 11}

"Tundukkan kepalamu. Hujan sedang mengantar bangkai tikus" (Hal 36).

Pada penggalan bait puisi terebut terdapat citraan gerak pada kata tundukkan kepalamu. Pengarang ingin menggugah daya bayang pembaca bahwa seakan-akan ada seorang yang sedang melakukan aktivitas gerak dengan cara menundukkan kepalanya.

Kutipan 12

"Daun-daun gugur yang tersungkur di atas batu" (Hal 63).

Pada penggalan bait puisi tersebut, terdapat citraan gerak pada kata daun-daun gugur. Pengarang ingin menggiring daya bayang pembaca bahwa seolah-olah daun-daun itu melakukan aktivitas gerak dengan cara gugur dari pohonnya.

\section{Kutipan 13}

"Saya cawan yang gemetar menyaksikan sekaratmu" (Hal 72).

Pada penggalan bait puisi tersebut, terdapat citraan gerak pada kata gemetar. Pengarang ingin menggugah daya bayang pembaca bahwa seolaholah cawan bisa melakukan aktivitas gerak layaknya manusia yang sedang ketakutan dengan reaksi gemetar.

Kutipan 14

"Tuhan bersama orang-orang mumet yang masih sempat sisiran" (90)

Pada penggalan bait puisi tersebut, terdapat citraan gerak pada kata sisiran. Pengarang ingin menggugah daya bayang pembaca bahwa ada seseorang yang melakukan aktivitas gerak yaitu sedang merapikan rambut atau sisiran.

\section{SIMPULAN}

Berdasarkan pemaparan hasil penelitian dan pembahasan, dapat disimpulkan bahwa terdapat 19 kutipan citraan penglihatan, 7 kutipan citraan pendengaran, dan 11 kutipan citraan gerak dalam 21 puisi dalam kumpulan puisi Surat Kopi karya Joko Pinurbo. 
Sehingga seluruh kutipan dari ketiga citraan itu terdapat 37 kutipan dari 21 puisi Surat Kopi karya Joko Pinurbo.

\section{Saran}

Berdasarkan hasil analisi data dan kesimpulan di atas, berikut ini disampaikan beberapa saran,

1. Bagi pembaca, hasil penelitian ini diharapkan dapat menjadi salah satu alternatif dalam memahami citraan yang terkandung dalam kumpulan puisi Surat Kopi karya Joko Pinurbo.

2. Bagi guru bahasa Indonesia, hasil penelitian ini diharapkan dapat dimanfaatkan untuk mengajarkan siswanya apa makna dan citraan yang terkandung dalam kumpulan puisi.

3. Bagi mahasiswa khususnya mahasiswa program studi Bahasa dan Sastra Indonesia, hasil penelitian ini hendaknya dapat dijadikan sumber pengetahuan baru mengenai citraan.

4. Bagi penulis selanjutnya, hasil penelitian ini diharapkan dapat melakukan penelitian yang lebih bervariasi, yakni pada kajian yang berbeda.

\section{DAFTAR PUSTAKA}

Damono, Sapardi Djoko. (2005). Pegangan Penelitian Sastra Bandingan. Jakarta: Pusat Pembinaan dan Pengembangan Bahasa. Departemen Pendidikan dan Kebudayaan.

Denzin, Norman K, dan Yvonna S. Lincoln (eds). (2014). Handbook of Qualitative Research. Terj.Dariyatno dkk. Yogyakarta: Pustaka Belajar

Moleong, Lexy J. (2014). Metodologi Penelitian Kualitatif.
Bandung: $\quad$ PT $\quad$ Remaja Rosdakarya.

Pradopo, Rachmad Djoko. (2014). Pengkajian Puisi. Yogyakarta: Gajahmada University Press.

Rahima, A. (2017). Literature Reception (aConceptual Overview). Jurnal Ilmiah Dikdaya, 6(1), 1-16.

Siswantoro. (2014). Metode Penelitian Sastra. Yogyakarta. Pustaka Pelajar.

Sugiyono. (2013). Metode Penelitian Kuantitatif, Kualitatif. Bandung: Alfabeta. 